\title{
PRODUKTIVITAS DAN BIAYA PENYARADAN KAYU DI HUTAN TANAMAN RAWA GAMBUT: STUDI KASUS DI SALAH SATU PERUSAHAAN HUTAN DI RIAU
}

\section{(Productivity and Cost of Log Skidding in Peat Swamp Forest Estate: A Case Study at a Forest Company in Riau)}

\author{
Oleh/By : \\ Sona Suhartana, Sukanda \& Yuniawati \\ Pusat Litbang Hasil Hutan, Jl. Gunung Batu No. 5, Bogor \\ Diterima 22 September 2008, disetujui 26 Juni 2009
}

\begin{abstract}
Skidding in peat swamp forest estate is different from skidding in dry land. Skidding method used were: manual, semi mechanized peat boat, full mechanized peat boat pulled by excavator. A study was carried out in PT Arara Abadi, Riau in May 2008. The aim of the study was to find out the productivity and cost of skidding in peat swamp forest estate. Data were analyzed by tabulation.

Result revealed that: (1) Skidding method in this company is carried out in dry peat swamp and wet peat swamp by three systems, namely manual (buman power), semi mechanized peat boat, and full mechanized peat boat; (2) The average of skidding productivity by full mechanized and semi mechanized are higher than manual, each are $27.79 \mathrm{~m}^{3} . \mathrm{mm} /$ hour and $25.61 \mathrm{~m}^{3} . \mathrm{hm} /$ hour due to higher volume of log skidded; (3) The average skidding cost of the semi mechanized (Rp $\left.18,190.5 / \mathrm{m}^{3} . \mathrm{hm}\right)$ and full mechanized systems (Rp 15,926.5 $\left./ \mathrm{m}^{3} . \mathrm{hm}\right)$, are both higher than the manual system (Rp1,203,8/ $\left.\mathrm{m}^{3} . \mathrm{hm}\right)$ because the first two systems are using high cost excavator.
\end{abstract}

Keywords: Skidding, peat swamp forest estate, productivity, cost.

\begin{abstract}
ABSTRAK
Penyaradan di hutan tanaman rawa gambut berbeda dengan penyaradan di lahan kering. Metode penyaradan yang digunakan adalah sistem manual dengan tenaga manusia, menggunakan sampan darat semi mekanis dan mekanis penuh yang ditarik ekskavator. Penelitian dilaksanakan pada bulan Mei 2008 di PT Arara Abadi, Riau. Tujuan penelitian adalah untuk mengetahui produktivitas dan biaya penyaradan di hutan tanaman rawa gambut. Data dianalisis dengan tabulasi dengan menghitung nilai rata-ratanya.

Hasil penelitian menunjukkan bahwa : (1). Sistem penyaradan yang dipergunakan di rawa gambut kering dan rawa gambut basah di areal perusahaan ini adalah sistem manual (tenaga manusia), sistem sampan darat semi mekanis (semi mekanis) dan sampan darat mekanis (mekanis penuh); (2) Rata-rata produktivitas penyaradan mekanis penuh dan semi mekanis lebih tinggi daripada menggunakan sistem manual, yaitu masing-masing $27,79 \mathrm{~m}^{3} . \mathrm{hm} / \mathrm{jam}$ dan $25,61 \mathrm{~m}^{3} . \mathrm{hm} / \mathrm{jam}$, dikarenakan volume kayu yang dapat disarad lebih besar; dan (3) Rata-rata biaya penyaradan sistem semi mekanis (Rp 18.190,5/m . $^{3} \mathrm{hm}$ ) dan mekanis penuh $\left(\operatorname{Rp~} 15.926,5 / \mathrm{m}^{3} . \mathrm{hm}\right)$ lebih tinggi daripada dengan sistem manual (Rp 1.203,8/ $\mathrm{m}^{3} . \mathrm{hm}$ ) karena pada kedua sistem terdahulu digunakan ekskavator yang biayanya tinggi.
\end{abstract}


Kata kunci: Penyaradan, hutan tanaman rawa gambut, produktivitas, biaya.

\section{PENDAHULUAN}

Penyaradan merupakan kegiatan memindahkan kayu dari tempat penebangan (tunggak) ke tempat pengumpulan kayu sementara (TPn) yang terletak di pinggir jalan angkutan. Penyaradan sebagai tahap awal dari kegiatan pengangkutan dengan tujuan memindahkan kayu dengan cepat dan murah (Elias, 2008; Conway, 1982)).

Sistem penyaradan mekanis banyak digunakan di hutan tanah kering adalah dengan traktor yang memiliki kapasitas lebih besar dibandingkan penyaradan sistem manual (tenaga manusia). Penerapan sistem penyaradan di hutan rawa gambut memiliki perbedaan dengan hutan lahan kering di mana banyak dilakukan dengan menggunakan tenaga manusia, maupun sampan darat/gerobak dari besi yang dirancang khusus untuk menyarad kayu yang ditarik oleh ekskavator. Penerapan sistem penyaradan di hutan rawa gambut memungkinkan pencapaian target produksi penyaradan yang lebih tinggi.

Produktivitas penyaradan dipengaruhi oleh ukuran kayu, topografi, cuaca, jarak sarad, keterampilan tenaga kerja dan keadaan tanah (Dipodiningrat, 1980). Tanah yang lembek, topografi yang berat, ukuran kayu yang kecil dan keterampilan tenaga yang rendah akan mengurangi produktivitas penyaradan.

Penyaradan manual mempunyai empat elemen kerja yakni berjalan kosong menuju kayu yang akan disarad, memuat kayu ke atas kuda-kuda dan menyarad kayu ke betou dan membongkar muatan ke atas betou. Uraian elemen kerja tersebut adalah sebagai berikut : (1). Berjalan kosong menuju kayu yang akan disarad, yakni regu sarad berjalan menuju kayu yang akan disarad sambil menarik alat kuda-kuda. Penarikan alat sarad menuju kayu yang akan disarad dilakukan oleh 2 orang; (2). Memuat, yakni kegiatan menaikkan kayu ke atas kudakuda sampai kayu siap disarad. Kegiatannya meliputi memasang penyangga pada alat sarad agar stabil, memasang landasan (ender-ender) sebagai tempat menggulingkan kayu ke kudakuda, mengungkit dan mendorong kayu ke atas alat kuda-kuda dengan menggunakan locak dan mengatur posisi kayu di atas alat sarad agar seimbang; (3). Menyarad, meliputi memasang tali penarik dan menyarad; (4). Membongkar dan mengatur kayu di betou dengan menggunakan locak (Muhdi, 2002).

Penyaradan kayu di hutan tanaman industri lahan gambut sangat spesifik karena lahan gambut sangat gembur di mana penyaradan dapat dilakukan dengan sistem manual (tenaga manusia), sitem semi mekanis dan mekanis dengan menggunakan sampan darat/gerobak dari besi yang dirancang khusus untuk menyarad kayu yang ditarik oleh ekskavator. Untuk itu dalam tulisan ini disajikan mengenai produktivitas dan biaya penyaradan dari ketiga sistem yang digunakan di hutan tanaman rawa gambut.

\section{METODOLOGI}

\section{A. Waktu dan Lokasi Penelitian}

Penelitian dilaksanakan pada bulan Mei 2008 di areal kerja HPHTI PT. Arara Abadi, 
Petak tebang 365, Distrik Berbari. Areal ini termasuk ke dalam wilayah Dinas Kehutanan Kabupaten Siak, Propinsi Riau. Berdasarkan letak geografisnya, kelompok hutan ini terletak di antara $00^{\circ} 47^{\prime}-01^{\circ} 09^{\prime} \mathrm{LU}$ dan $102^{\circ} 04^{\prime}-102^{\circ} 13^{\prime} \mathrm{BT}$.

Keadaan areal penelitian memiliki kemiringan lapangan antara 0 - 8\% dengan ketinggian tempat antara 8-100 meter dari permukaan laut. Jenis tanah berupa organosol fibrist. Ada pun tipe iklim menurut Schmidt \& Ferguson termasuk tipe A dengan curah hujan bulanan 218,3 $\mathrm{mm}$ dan tidak mempunyai bulan kering. Tegakan pada areal penelitian adalah tegakan Acacia crassicarpa yang memiliki kerapatan antara 600-800 pohon/ha (untuk pohon berdiameter 10 $\mathrm{cm}$ ke atas). Tumbuhan bawah memiliki kerapatan jarang.

\section{B. Bahan dan Alat Penelitian}

Bahan yang digunakan adalah meteran dan pengukur waktu (stopwatch); sedangkan alat yang digunakan adalah alat tulis, komputer, sampan darat dan ekskavator (alat yang dioperasikan di lapangan).

\section{Prosedur Penelitian}

Kegiatan penyaradan dilakukan dengan tiga cara yaitu :

1. Sistim manual (tenaga manusia)

Penyaradan kayu sistem manual di hutan tanaman rawa gambut menggunakan ongkak yang ditarik oleh tenaga manusia. Satu regu penyarad terdiri dari 2 orang yang bertugas memuat, menarik dan membongkar muatan.

2. Sampan darat semi mekanis

Penyaradan kayu dengan sampan darat merupakan kegiatan pengumpulan kayu dari tempat tebangan ke pinggir sungai dengan menggunakan sampan/gerobak dari besi yang dirancang khusus untuk menyarad kayu di hutan rawa gambut yang ditarik oleh ekskavator. Kayu hasil tebangan dikumpulan pada satu tumpukan dengan tenaga manusia yang selanjutnya dimuat ke gerobak dan ditarik olek ekskavator.

3. Sampan darat sistem mekanis

Penyaradan kayu dengan sampan darat sistem mekanis merupakan kegiatan pengumpulan kayu dari tempat tebangan ke pinggir sungai dengan menggunakan sampan/gerobak dari besi yang dirancang khusus untuk menyarad kayu di hutan rawa gambut yang ditarik oleh ekskavator. Pemuatan kayu hasil tebangan dan penarikan sampan dilakukan oleh ekskavator.

Dalam RKT tahun berjalan, perusahaan memungut kayu dari areal seluas 44.747,46 ha dengan target produksi kayu 6.765.630,02 $\mathrm{m}^{3}$ dan rata-rata produksi kayu per tahun 4.000.000 $\mathrm{m}^{3}$ terdiri dari jenis kayu Acacia crassicarpa (Anonim, 2008).

Penelitian dilaksanakan melalui tahap kegiatan sebagai berikut:

1. Menetapkan secara purposif 1 petak tebang ( $25 \mathrm{ha}$ ) yang segera dilakukan penebangan dan penyaradan;

2. Melakukan penyaradan dengan sistem manual, semi mekanis dan mekanis dengan masing-masing ulangan adalah 5 rit. Dalam 1 rit rata-rata memuat 7 batang (manual), 260 batang (semi mekanis) dan 273 batang (mekanis) dengan ukuran rata-rata diameter 16,5 cm dan panjang $2,5 \mathrm{~m}$; 
3. Pengukuran produktivitas penebangan dan biaya produksi penyaradan adalah sebagai berikut:

a. Produktivitas penyaradan dihitung dengan cara mencatat waktu sarad dengan metode nul-stop, jarak sarad dan volume kayu yang disarad;

b. Biaya produksi penyaradan dengan cara mencatat semua pengeluaran seperti pemakaian bahan bakar, oli/pelumas, upah, produktivitas, biaya penyusutan, biaya pemeliharaan/perbaikan, bunga, asuransi dan pajak.

4. Mencatat data umum sebagai berikut: keadaan umum lapangan dan keadaan umum perusahaan yang dikutip dari perusahaan dan wawancara dengan karyawan.

\section{Analisis Data}

Data lapangan berupa produktivitas sarad dari masing-masing sistem penyaradan, diolah ke dalam bentuk tabulasi dengan menghitung nilai rata-ratanya.

1. Produktivitas sarad dihitung dengan rumus berikut:

$$
\mathrm{P}=\frac{\mathrm{VxJ}}{\mathrm{W}}
$$

di mana: Ps $=$ produktivitas $\operatorname{sarad}\left(\mathrm{m}^{3} \cdot \mathrm{hm} / \mathrm{jam}\right) ; \mathrm{J}=$ jarak $\operatorname{sarad}(\mathrm{hm}) ; \mathrm{W}=$ waktu kerja sarad (jam); $\mathrm{V}=$ volume kayu $\left(\mathrm{m}^{3}\right)$ diperoleh dari $\mathrm{V}=0,25 \Lambda \mathrm{D}^{2} \mathrm{~L}$

di mana: $\mathrm{JL}=$ konstanta 3,1416; $\mathrm{L}=$ panjang batang $(\mathrm{m}) ; \mathrm{D}=$ diameter rata-rata $(\mathrm{m})$ diperoleh dari: $\mathrm{D}=0,5(\mathrm{Dp}+\mathrm{Du})$ di mana $\mathrm{Dp}=$ diameter pangkal dan $\mathrm{Du}=$ diameter ujung.

2. Biaya penyaradan dihitung dengan menggunakan rumus dari FAO (Anonim, 1992) sebagai berikut:

$$
\begin{aligned}
& \mathrm{Bs}=\frac{\mathrm{BP}+\mathrm{BA}+\mathrm{BB}+\mathrm{Pj}+\mathrm{BBB}+\mathrm{BO}+\mathrm{BPr}+\mathrm{UP}}{\mathrm{Ps}} \\
& \mathrm{BP}=\frac{\mathrm{H} \times 0,9}{\mathrm{UPA}} \\
& \mathrm{BA}=\frac{\mathrm{H} \times 0,6 \times 3 \%}{\mathrm{JT}} \\
& \mathrm{BB}=\frac{\mathrm{H} \times 0,6 \times 15 \%}{\mathrm{JT}} \\
& \mathrm{Pj}=\frac{\mathrm{H} \times 0,6 \times 2 \%}{\mathrm{JT}}
\end{aligned}
$$


$\mathrm{BBB}=0,20 \times \mathrm{HP} \times 0,54 \times \mathrm{HBB}$

$\mathrm{BO}=0,1 \times \mathrm{BBB}$

di mana : Bs = Biaya sarad $\left(\mathrm{Rp} / \mathrm{m}^{3} \cdot \mathrm{hm}\right) ; \mathrm{BO}=$ Biaya oli $/$ pelumas $(\mathrm{Rp} / \mathrm{jam}) ; \mathrm{H}=$ Harga alat $(\mathrm{Rp}) ; \mathrm{BP}=$ Biaya penyusutan $(\mathrm{Rp} / \mathrm{jam}) ; \mathrm{Ps}=$ produktivitas sarad $\left(\mathrm{m}^{3} . \mathrm{hm} / \mathrm{jam}\right) ; \mathrm{BA}=$ Biaya asuransi $(\mathrm{Rp} / \mathrm{jam}) ; \mathrm{Up}=\mathrm{Upah}$ pekerja $(\mathrm{Rp} / \mathrm{jam}) ; \mathrm{BB}$ $=$ Biaya bunga $(\mathrm{Rp} / \mathrm{jam}) ; \mathrm{Pj}=$ Biaya pajak $(\mathrm{Rp} / \mathrm{jam}) ; \mathrm{BBB}=$ Biaya bahan bakar $(\mathrm{Rp} / \mathrm{jam}) ; \mathrm{Bpr}=$ Biaya pemeliharaan $(\mathrm{Rp} / \mathrm{jam}) ; \mathrm{HBB}=$ Harga bahan bakar $(\mathrm{Rp} /$ liter); UPA = Umur pakai alat (jam); JT = Jam kerja alat per tahun (jam); dan HP = Besar daya.

\section{HASIL DAN PEMBAHASAN}

\section{A. Waktu Kerja, Jarak Sarad dan Volume Kayu}

Waktu kerja penyaradan dibagi dalam dua bagian yaitu waktu kerja efektif dan tidak efektif. Waktu kerja efektif didefinisikan sebagai waktu yang digunakan untuk menyelesaikan setiap elemen kerja penyaradan yaitu: pada saat tenaga manusia dan sampan darat baik semi mekanis dan mekanis penuh mengumpulkan kayu dari tempat tebangan menuju pinggir sungai untuk selanjutnya ditarik oleh ekskavator. Waktu kerja tidak efektif terdiri dari unsur kerja tidak efektif yaitu adanya gangguan ketika penyaradan beroperasi di antaranya kerusakan alat, kayu yang disarad tersangkut dan ketidakteraturan kayu saat pemuatan.

Hasil dari pengukuran waktu kerja pada berbagai jarak sarad dan volume penyaradan sistem manual disajikan pada Tabel1.

Tabel1. Rata-rata waktu kerja, jarak dan volume penyaradan cara manual

Table 1. Average skidding time, skidding distance and log volume of manual technique

\begin{tabular}{|c|c|c|c|c|c|c|c|}
\hline \multirow{2}{*}{$\begin{array}{c}\text { Ulangan/ } \\
\text { Reflication }\end{array}$} & \multirow{2}{*}{$\begin{array}{c}\text { Jarak sarad/ } \\
\text { Skidding distance }\end{array}$} & \multirow{2}{*}{$\begin{array}{c}\text { Volume kayu/ } \\
\text { Log volume } \\
(\mathrm{m})\end{array}$} & \multicolumn{4}{|c|}{ Waktu sarad, menit/ Skidding time, minute } \\
\cline { 4 - 8 } & & & $\begin{array}{c}\text { Masuk/ } \\
\text { In }\end{array}$ & $\begin{array}{c}\text { Muat/ } \\
\text { Loading }\end{array}$ & $\begin{array}{c}\text { Sarad/ } \\
\text { Skidding }\end{array}$ & $\begin{array}{c}\text { Bongkar/ } \\
\text { Unloading }\end{array}$ & Total \\
\hline 1 & 100 & 0,32 & 1,05 & 5,33 & 1,35 & 6,05 & 13,78 \\
\hline 2 & 150 & 0,35 & 1,17 & 5,17 & 1,50 & 6,00 & 13,83 \\
\hline 3 & 200 & 0,37 & 2,00 & 5,42 & 2,50 & 6,08 & 16,00 \\
\hline 4 & 75 & 0,30 & 1,00 & 5,25 & 1,17 & 6,03 & 13,45 \\
\hline 5 & 120 & 0,33 & 1,08 & 5,08 & 1,42 & 5,97 & 14,08 \\
\hline $\begin{array}{c}\text { Rata-Rata/ } \\
\text { Mean }\end{array}$ & 135 & 0,34 & 1,77 & 5,25 & 1,58 & 6,03 & 14,13 \\
\hline$\%$ & & & 8,9 & 37,2 & 11,2 & 42,7 & 100 \\
\hline
\end{tabular}


Dari Tabel 1 terlihat bahwa rata-rata total waktu penyaradan sistem manual adalah 14,13 menit pada jarak sarad rata-rata $135 \mathrm{~m}$ dan rata-rata volume kayu yang disarad $0,34 \mathrm{~m}^{3}$, paling besar pada waktu bongkar yaitu 6,03 menit (42,7\%), waktu muat 5,25 menit (37,2\%), waktu sarad 1,58 menit $(11,2 \%)$ dan waktu masuk 1,77 menit $(8,9 \%)$. Kecilnya total waktu yang diperlukan untuk menyarad pada sistem manual dikarenakan kondisi lahan berupa rawa gambut kering, di mana kondisi tersebut tidak terlalu banyak gangguan alam seperti di rawa gambut yang tergenang air serta volume kayu yang disarad relatif sedikit.

Hasil pengukuran waktu kerja, jarak dan volume sarad dengan sampan darat semi mekanis disajikan pada Tabel 2.

Tabe1 2. Rata-rata waktu kerja, jarak dan volume sarad kayu dengan sampan darat semi mekanis

Table 2. Average skidding time, skidding distance and log volume of semi mechanized peatboat

\begin{tabular}{|c|c|c|c|c|c|c|c|}
\hline \multirow{2}{*}{$\begin{array}{l}\text { Ulangan/ } \\
\text { Reflication }\end{array}$} & \multirow{2}{*}{$\begin{array}{c}\text { Jarak sarad/ } \\
\text { Skidding distance } \\
\text { (m) }\end{array}$} & \multirow{2}{*}{$\begin{array}{c}\text { Volume kayu/ } \\
\text { Log volume } \\
\left(\mathrm{m}^{3}\right)\end{array}$} & \multicolumn{5}{|c|}{ Waktu sarad, menit/ Skidding time, minute } \\
\hline & & & $\begin{array}{c}\text { Masuk/ } \\
\text { In }\end{array}$ & $\begin{array}{l}\text { Muat/ } \\
\text { Loading }\end{array}$ & $\begin{array}{l}\text { Sarad/ } \\
\text { Skidding }\end{array}$ & $\begin{array}{l}\text { Bongkar/ } \\
\text { Unloading }\end{array}$ & Total \\
\hline 1 & 240 & 12,36 & 7,50 & 10,00 & 30,00 & 9,00 & 56,50 \\
\hline 2 & 230 & 11,40 & 7,17 & 10,35 & 28,67 & 9,03 & 55,38 \\
\hline 3 & 250 & 11,40 & 7,58 & 10,17 & 30,33 & 9,17 & 57,25 \\
\hline 4 & 175 & 12,36 & 7,08 & 10,25 & 26,67 & 8,92 & 52,92 \\
\hline 5 & 100 & 11,40 & 6,67 & 10,08 & 25,33 & 9,08 & 51,17 \\
\hline $\begin{array}{c}\text { Rata-Rata/ } \\
\text { Mean }\end{array}$ & 209 & 13,05 & 7,20 & 10,17 & 28,20 & 9,03 & 54,62 \\
\hline$\%$ & & & 13,2 & 18,6 & 51,6 & 16,6 & 100 \\
\hline
\end{tabular}

Dari Tabel 2 dapat dilihat bahwa rata-rata waktu kerja paling besar pada saat menyarad kayu yaitu 28,20 menit (51,64\%), waktu muat 10,17 menit (18,6\%), waktu bongkar 9,03 menit $(16,6 \%)$ dan waktu masuk/berjalan kosong 7,20 menit $(13,2 \%)$. Total waktu yang diperlukan dengan menggunakan sampan semi mekanis adalah 54,62 menit pada jarak sarad rata-rata 209 $\mathrm{m}$ dan rata-rata volume kayu yang disarad $13,05 \mathrm{~m}^{3}$. Namun demikian lamanya waktu penggunaan sampan tersebut dapat dimengerti karena jumlah volume yang disarad dengan cara semi mekanis lebih banyak, yaitu 13,05 $\mathrm{m}^{3}$ (Tabel 2 kolom 3) dibandingkan dengan volume kayu dengan sistem manual yaitu $0,34 \mathrm{~m}^{3}$ (Tabel 1 kolom 3 ).

Hasil pengukuran waktu kerja, jarak dan volume kayu yang disarad dengan sampan darat mekanis penuh disajikan pada Tabel 3. Dari Tabel 3 dapat dilihat bahwa rata-rata waktu kerja paling besar adalah pada saat sarad/berjalan isi yaitu 26,07 menit (45,7\%), waktu muat 14,97 menit (26,3\%), waktu bongkar muatan 8,98 menit (15,7\%) dan waktu masuk/berjalan kosong 7,00 menit $(12,3 \%)$. Total waktu yang diperlukan dengan menggunakan sampan darat mekanis penuh 57,02 menit pada rata-rata jarak sarad $200 \mathrm{~m}$ dan rata-rata volume kayu yang disarad 13,68 $\mathrm{m}^{3}$. Namun demikian lamanya waktu penggunaan sampan tersebut dapat dimengerti karena jumlah volume yang disarad dengan cara mekanis lebih banyak, yaitu 13,68 $\mathrm{m}^{3}$ (Tabel 3 kolom3) dan manual $0,34 \mathrm{~m}^{3}$ (Tabel 1 kolom 3). 
Tabel3. Rata-rata waktu kerja, jarak dan volume sarad dengan sampan darat mekanis penuh

Table 3. Average skidding time, skidding distance and log volume of fullmechanized peat boat

\begin{tabular}{|c|c|c|c|c|c|c|c|}
\hline \multirow{2}{*}{$\begin{array}{l}\text { Ulangan/ } \\
\text { Reflication }\end{array}$} & \multirow{2}{*}{$\begin{array}{l}\text { Jarak sarad/ } \\
\text { Skidding distance } \\
\text { (m) }\end{array}$} & \multirow{2}{*}{$\begin{array}{c}\text { Volume kayu/ } \\
\text { Log volume } \\
\left(\mathrm{m}^{3}\right)\end{array}$} & \multicolumn{5}{|c|}{ Waktu sarad, menit/Skidding time, minute } \\
\hline & & & $\begin{array}{c}\text { Masuk/ } \\
\text { In }\end{array}$ & $\begin{array}{l}\text { Muat/ } \\
\text { Loading }\end{array}$ & $\begin{array}{l}\text { Sarad/ } \\
\text { Skidding }\end{array}$ & \begin{tabular}{|c|} 
Bongkar/ \\
Unloading
\end{tabular} & Total \\
\hline 1 & 225 & 13,68 & 7,00 & 16,00 & 26,67 & 9,08 & 58,75 \\
\hline 2 & 150 & 13,15 & 6,00 & 14,50 & 20,00 & 9,00 & 49,05 \\
\hline 3 & 200 & 12,62 & 7,50 & 15,33 & 28,67 & 9,33 & 60,83 \\
\hline 4 & 175 & 13,15 & 6,50 & 14,00 & 25,00 & 8,67 & 54,17 \\
\hline 5 & 250 & 13,68 & 8,00 & 15,00 & 30,00 & 8,83 & 61,83 \\
\hline $\begin{array}{c}\text { Rata-rata } \\
\text { Mean }\end{array}$ & 200 & 13,68 & 7,00 & 14,97 & 26,07 & 8,98 & 57,02 \\
\hline$\%$ & & & 12,3 & 26,3 & 45,7 & 15,7 & 100 \\
\hline
\end{tabular}

\section{B. Produktivitas Kerja}

Produktivitas kerja untuk masing-masing cara penyaradan dihitung dengan menggunakan data Tabel 1 sampai Tabel 3 di muka dan hasilnya disajikan pada Tabel 4.

Tabel 4. Rata-rata produktivitas penyaradan

Table 4. Average skidding productivity

\begin{tabular}{|l|c|c|c|c|}
\hline \multicolumn{1}{|c|}{$\begin{array}{c}\text { Sistem penyaradan/ } \\
\text { Skidding system }\end{array}$} & $\begin{array}{c}\text { Waktu sarad, } \\
\text { menit/Skidding } \\
\text { time, minute }\end{array}$ & $\begin{array}{c}\text { Volume } \\
\left(\mathrm{m}^{3}\right)\end{array}$ & $\begin{array}{c}\text { Jarak sarad/ } \\
\text { Skidding } \\
\text { distance }(\mathrm{m})\end{array}$ & $\begin{array}{c}\text { Produktivitas, } \\
\mathrm{m}^{3} \cdot \mathrm{hm} / \mathrm{jam} / \\
\text { Productivity, } \\
\mathrm{m}^{3} . \text { hm/ hour }\end{array}$ \\
\hline Manual/Manual & 14,13 & 0,34 & 135 & 12,456 \\
\hline $\begin{array}{l}\text { Sampan darat semi } \\
\text { mekanis/Semi mechanized } \\
\text { peat boat. }\end{array}$ & 54,62 & 13,05 & 209 & 25,508 \\
\hline $\begin{array}{l}\text { Sampan darat mekanis/ } \\
\text { Full-mechanized peat boat. }\end{array}$ & 57,02 & 13,68 & 200 & 27,788 \\
\hline
\end{tabular}

Keterangan/Remark: Jumlah ulangan/Replication $=5$.

Tabel 4 menunjukkan bahwa produktivitas kerja penyaradan dengan menggunakan sampan darat baik semi mekanis maupun mekanis lebih tinggi daripada menggunakan sistem manual (tenaga manusia). Hal ini disebabkan pada sampan darat semi mekanis dan mekanis kapasitas muatnya besar yaitu1 $13,05 \mathrm{~m}^{3}$ dan $13,68 \mathrm{~m}^{3}$. Untuk penyaradan di rawa gambut kering dengan tenaga manusia menghasilkan rata-rata produktivitas lebih kecil daripada penggunaan sampan darat. Hal ini dikarenakan satu regu penyarad terdiri dari 2 orang yang bertugas memuat, menarik dan membongkar muatan. Satu kali tarik menyarad kayu 0,30 
sampai $0,37 \mathrm{~m}^{3}$ akibatnya rata-rata volume kayu yang dapat ditarik oleh regu penyarad $0,34 \mathrm{~m}^{3}$. Keterbatasan tenaga manusia menyebabkan volume kayu yang dapat disarad sangat terbatas.

Untuk mengetahui sistem penyaradan yang efisien dari aspek produktivitas, telah dilakukan uji-t dari masing-masing sistem yang disajikan pada Tabel 5 berikut:

Tabel 5. Hasil uji- t tiga cara penyaradan dari aspek produktivitas Table 5. Result of t-test of 3 skidding techniques from productivity aspect

\begin{tabular}{|l|c|c|}
\hline \multicolumn{1}{|c|}{ Sistem penyaradan/Skidding system } & T- hitung/T-calc. & $\begin{array}{c}\text { T-tabel /T-table } \\
(99 \%)\end{array}$ \\
\hline $\begin{array}{l}\text { Manual/Manul >< Sampan darat semi } \\
\text { mekanis/Semi mechanized peat boat }\end{array}$ & $3,513^{* *}$ & 3,355 \\
\hline $\begin{array}{l}\text { Manual/Manuly >< Sampan darat mekanis } \\
\text { penuh/Full mechanized peat boat }\end{array}$ & $5,823^{* *}$ & 3,355 \\
\hline $\begin{array}{l}\text { Sampan darat semi mekanis/Semi mechanized } \\
\text { peat boat }><\text { Sampan darat mekanis } \\
\text { penuh/Full mechanized peat boat }\end{array}$ & 0,578 & 3,355 \\
\hline
\end{tabular}

Dari Tabel 5, telihat bahwa hasil uji-t antara penyaradan Sistem manual $><$ Sampan darat semi mekanis berbeda sangat nyata pada tingkat kepercayaan 99\%. Hal ini mengandung arti bahwa dari aspek produktivitas sistem penyaradan dengan sampan darat semi mekanis lebih baik dari pada sistem manual. Pengujian Sistem manual $><$ Sampan darat mekanis penuh berbeda sangat nyata pada tingkat kepercayaan 99\%. Hal ini dapat dikatakan bahwa dari aspek produktivitas sistem penyaradan dengan sampan darat mekanis penuh lebih naik dari pada sistem manual. Pengujian Sampan darat semi mekanis $><$ Sampan darat mekanis penuh perbedaannya tidak nyata. Dengan demikian dari pengujian tersebut dapat diambil kesimpulan bahwa dari aspek produktivitas sistem penyaradan dengan sampan darat mekanis penuh layak diterapkan sesuai kondisi penelitian di atas.

\section{Biaya Penyaradan}

\section{Penyaradan dengan sistem manual}

Penyaradan sistem manual menggunakan tenaga manusia, maka untuk mengetahui biaya penyaradan dilakukan dengan pendekatan upah harian dibagi dengan prestasi kerja. Dengan upah Rp 15.000/jam/regu, produktivitas kerja 12,46 $\mathrm{m}^{3} \mathrm{hm} / \mathrm{jam}$, maka biaya penyaradan kayu sistem manual dengan tenaga manusia di hutan tanaman rawa gambut adalah Rp $1.203,8 / \mathrm{m}^{3} . \mathrm{hm}$.

\section{Penyaradan dengan sampan darat semi mekanis}

Untuk mengetahui rata-rata biaya penyaradan dengan sampan darat semi mekanis maka dilakukan analisis biaya alat ekskavator Hitachi dengan tenaga motor $180 \mathrm{HP}$ yang digunakan untuk penyaradan kayu. Harga alat pada tahun 2008 Rp 795.150.000, waktu kerja alat 1000 jam per tahun dengan jam kerja perhari 8 jam, konsumsi solar 25 liter per jam dengan harga Rp 6000/liter, konsumsi oli 0,1 liter/jam dan upah operator Rp 150.000/hari. Dari data tersebut di atas diperoleh biaya penggunaan alat per jam seperti disajikan pada Tabel 6. 
Kemudian berdasarkan rata-rata produktivitas dan biaya mesin pada Tabel 6 maka dapat dihitung rata-rata biaya penyaradan sistem semi mekanis dengan menggunakan ekskavator Hitachi, yaitu sebesar Rp 18.190,5/ $\mathrm{m}^{3} . \mathrm{hm}$.

Tabel 6. Biaya pemilikan dan operasi ekskavator Hitachi untuk penyaradan kayu Table 6. Owning and operating cost of Hitachi excavator for log skidding

\begin{tabular}{|l|c|}
\multicolumn{1}{|c|}{$\begin{array}{c}\text { Komponen biaya/ } \\
\text { Cost components }\end{array}$} & $\begin{array}{c}\text { Jumlah (Rp/jam)/ } \\
\text { Amount (Rp/ hour) }\end{array}$ \\
\hline Biaya penyusutan/Depreciation cost & $71.563,00$ \\
\hline Biaya asuransi/Insurance cost & $14.312,70$ \\
\hline Biaya bunga/Interest cost & $71.563,00$ \\
\hline Biaya pajak/Taxes cost & $9.541,80$ \\
\hline Biaya bahan bakar/Fuel cost & $150.000,00$ \\
\hline Biaya Oli/pelumas/Oil and grease cost & $15.000,00$ \\
\hline Biaya perbaikan/pemeliharaan/Servicing and repairing cost & $71.563,00$ \\
\hline Biaya upah/Wages cost & $18.750,00$ \\
\hline Total biaya / Total cost & $422.293,50$ \\
\hline
\end{tabular}

3. Penyaradan dengan sampan darat sistem mekanis

Untuk mengetahui rata-rata biaya penyaradan dengan sampan darat sistem mekanis dilakukan analisis biaya alat yang digunakan untuk penyaradan kayu yaitu ekskavator Caterpillar 328 dengan tenaga motor 180 HP. Harga alat pada tahun 2008 Rp 837.000.000, waktu kerja alat 1000 jam per tahun dengan jam kerja per hari 8 jam, konsumsi solar 25 liter per jam dengan harga Rp 6000/liter, konsumsi oli 0,1 liter/jam dan upah operator Rp 150.000/hari. Dari data tersebut maka diperoleh biaya penggunaan alat per jam seperti disajikan pada Tabel 7.

Tabel 7. Biaya pemilikan dan operasi ekskavator Caterpillar 328 untuk penyaradan kayu

Table 7. Owning and operating cost of Caterpillar 328 excavator for log skidding

\begin{tabular}{|l|c|}
\multicolumn{1}{|c|}{$\begin{array}{c}\text { Komponen biaya/ } \\
\text { Cost components }\end{array}$} & $\begin{array}{c}\text { Jumlah (Rp/jam)/ } \\
\text { Amount (Rp/ hour) }\end{array}$ \\
\hline Biaya penyusutan/Depreciation cost & 75.330 \\
\hline Biaya asuransi/Insurance cost & 15.006 \\
\hline Biaya bunga/Interest cost & 75.330 \\
\hline Biaya pajak/Taxes cost & 10.044 \\
\hline Biaya bahan bakar/Fuel cost & 150.000 \\
\hline Biaya Oli/pelumas/Oil and grease cost & 15.000 \\
\hline Biaya perbaikan/pemeliharaan/Servicing and repairing cost & 75.330 \\
\hline Biaya upah/Wages cost & 18.750 \\
\hline Total biaya / Total cost & 434.790 \\
\hline
\end{tabular}


Berdasarkan rata-rata produktivitas kerja dan biaya mesin maka dapat dihitung rata-rata biaya penyaradan dengan sampan darat sistem mekanis dengan menggunakan ekskavator Caterpillar 328 adalah sebesar Rp $15.926,5 / \mathrm{m}^{3} . \mathrm{hm}$. Besarnya biaya penyaradan dengan sampan darat mekanis ternyata lebih rendah dibanding dengan sampan darat semi mekanis, akan tetapi lebih tinggi daripada biaya penyaradan manual. Hal ini dapat dimengerti karena dengan sistem mekanis dapat menghasilkan produktivitas sarad yang tinggi juga pada penggunaan sampan darat untuk kegiatan berikutnya menggunakan ekskavator sehingga memerlukan biaya komponen mesin.

Dari uraian di atas, dapat disajikan rata-rata biaya penyaradan untuk masing-masing sistem penyaradan seperti terlihat pada Tabel 8 berikut:

Tabe 8. Rata-rata biaya penyaradan

Table 8. Average skidding cost

\begin{tabular}{|l|c|c|c|}
\hline \multicolumn{1}{|c|}{$\begin{array}{c}\text { Sistem penyaradan/ } \\
\text { Skidding system }\end{array}$} & $\begin{array}{c}\text { Produktivitas, } \\
\mathrm{m}^{3} \cdot \mathrm{hm} / \mathrm{jam} / \\
\text { Productivity, } \\
\mathrm{m}^{3} \cdot \mathrm{hm} / \text { hour }\end{array}$ & $\begin{array}{c}\text { Biaya, Rp per } \\
\text { jam/Cost, } \\
\mathrm{Rp} / \text { hour }\end{array}$ & $\begin{array}{c}\text { Biaya penyaradan, } \\
\mathrm{Rp} / \mathrm{m}^{3} \cdot \mathrm{hm} / \\
\text { Skidding cost, Rp/ } \\
\mathrm{m}^{3} \cdot \mathrm{hm}\end{array}$ \\
\hline Manual/Manual & 12,46 & 15.000 & $1.203,8$ \\
\hline $\begin{array}{l}\text { Sampan darat semi } \\
\text { mekanis/ }\end{array}$ & 25,608 & $422.293,50$ & $18.190,526$ \\
$\begin{array}{l}\text { Semi mechanized peat } \\
\text { boat. }\end{array}$ & 27,788 & $434.790,00$ & $15.926,50$ \\
\hline $\begin{array}{l}\text { Sampan darat mekanis } \\
\text { /Full-mechanized peat } \\
\text { boat. }\end{array}$ & & & \\
\hline
\end{tabular}

Untuk mengetahui sistem penyaradan yang efisien dari aspek biaya, telah dilakukan uji-t dari masing-masing teknik yang disajikan pada Tabel 9 berikut:

Tabe1 9. Hasil uji- $\mathrm{t}$ tiga sistem penyaradan dari aspek biaya sarad Table 9. Result of t-test of 3 skidding systems from skidding cost aspect

\begin{tabular}{|l|c|c|}
\hline \multicolumn{1}{|c|}{ Sistem penyaradan/Skidding system } & T-hitung/T-calc. & $\begin{array}{c}\text { T-tabel/T-table } \\
(99 \%)\end{array}$ \\
\hline $\begin{array}{l}\text { Manual/Manual >< Sampan darat semi } \\
\text { mekanis/Semi mechanized peat boat }\end{array}$ & $4,967 * *$ & 3,355 \\
\hline $\begin{array}{l}\text { Manual/Manual >< Sampan darat mekanis } \\
\text { penuh/Full mechanized peat boat }\end{array}$ & $13,812^{* *}$ & 3,355 \\
\hline $\begin{array}{l}\text { Sampan darat semi mekanis/Semi mechanize } \\
\text { peat boat >< Sampan darat mekanis } \\
\text { penuh/Full mechanized peat boat }\end{array}$ & 0,639 & 3,355 \\
\hline
\end{tabular}


Dari Tabel 9, telihat bahwa hasil uji-t dari aspek biaya antara penyaradan sistem manual $><$ Sampan darat semi mekanis berbeda sangat nyata pada tingkat kepercayaan 99\%. Hal ini mengandung arti bahwa dari aspek biaya penyaradan sistem manual lebih baik dibandingkan dengan sampan darat semi mekanis. Pengujian sistem penyaradan manual $><$ sampan darat mekanis penuh berbeda sangat nyata pada tingkat kepercayaan $99 \%$. Hal ini mengandung arti bahwa dari aspek biaya penyaradan sistem manual lebih baik daripada sampan darat mekanis penuh. Pengujian biaya penyaradan dengan sampan darat semi mekanis $><$ sampan darat mekanis penuh perbedaannya tidak nyata. Dengan demikian dari pengujian tersebut dapat diambil kesimpulan bahwa dari aspek biaya penyaradan, sistim manual lebih baik daripada system lainnya. Akan tetapi penyaradan sistim manual kurang efektif karena tenaga manusia sulit diperoleh dan tidak akan efektif pada skala produksi besar dan terbukti dari aspek produktivitas lebih rendah.

\section{KESIMPULAN}

Penyaradan di perusahaan ini dilakukan dengan tiga sistem yaitu sistem manual (tenaga manusia), sistem sampan darat semi mekanis (semi mekanis) dan sampan darat mekanis (mekanis penuh).

1. Rata-rata waktu kerja penyaradan sistem manual adalah 14,13 menit, paling besar pada waktu bongkar yaitu 6,03 menit (42,7\%), diikuti waktu muat 5,25 menit (37,2\%), waktu $\operatorname{sarad} 1,58$ menit $(11,2 \%)$ dan waktu masuk 1,27 menit $(8,9 \%)$.

2. Rata-rata waktu kerja penyaradan sistem sampan darat semi mekanis adalah 54,62 menit, paling besar pada saat menyarad kayu yaitu 28,2 menit (51,6\%), kemudian waktu muat 10,17 menit (18,6\%), waktu bongkar 9,03 menit (16,5\%) dan waktu masuk/berjalan kosong 7,20 menit $(13,2 \%)$.

3. Rata-rata waktu kerja penyaradan sastem sampan darat mekanis penuh adalah 57,02 menit, paling besar adalah pada saat sarad/berjalan isi yaitu 26,07 menit (45,7\%), diikuti waktu muat 14,97 menit $(26,3 \%)$, waktu bongkar muatan 8,98 menit $(15,7 \%)$ dan waktu masuk/ berjalan kosong 7 menit (12,3\%).

4. Rata-rata produktivitas sarad menggunakan sampan darat mekanis penuh $(27,79$ $\left.\mathrm{m}^{3} \cdot \mathrm{hm} / \mathrm{jam}\right)$, dan semi mekanis $\left(25,61 \mathrm{~m}^{3} . \mathrm{hm} / \mathrm{jam}\right)$ lebih tinggi dari pada menggunakan sistem manual $\left(12,46 \mathrm{~m}^{3} . \mathrm{hm} / \mathrm{jam}\right)$ dikarenakan volume kayu yang dapat disarad lebih besar.

5. Rata-rata biaya penyaradan dengan menggunakan sampan darat baik semi mekanis (Rp $\left.18.190,5 / \mathrm{m}^{3} . \mathrm{hm}\right)$ maupun mekanis $\left(\mathrm{Rp} 15.926,5 \mathrm{~m}^{3} . \mathrm{hm}\right)$ lebih tinggi daripada dengan sistem manual (Rp $\left.1.023,8 / \mathrm{m}^{3} . \mathrm{hm}\right)$. Hal ini dikarenakan pada penggunaan sampan darat untuk kegiatan berikutnya menggunakan ekskavator sehingga memerlukan biaya komponen mesin. 


\section{DAFTAR PUSTAKA}

Anonim. 1992. Cost control in forest harvesting and road construction. FAO Forestry Paper No. 99, FAO of the UN. Rome.

2008. Rencana Kerja Tahunan Tahun 2008. PT. Arara Abadi. Pekanbaru.

Conway, S. 1982. Logging Practices. Revised Eition. Miller Freeman Publication Inc. New York.

Dipodiningrat, S. 1980. Prestasi kerja dan biaya traktor sarad (Studi kasus di PT BFI Kalimantan Timur). Proc. Seminar Eksploitasi Hutan. Lembaga Penelitian Hasil Hutan. Bogor.

Elias. 2008. Pembukaan Wilayah Hutan. IPB Press. Bogor.

Muhdi. 2002. Penyaradan kayu dengan sistem kuda-kuda di hutan rawa gambut (Studi Kasus di Areal HPH PT Kurnia Musi Plywood Industrial Co. Ltd, Prop. Sumatera Selatan). Fakultas Kehutanan, Program Ilmu Kehutanan. Universitas Sumatera Utara. Medan.

Sribudiani, E. 2002. Beban kerja fisik penyarad kayu sistem kuda-kuda (Studi di hutan alam HPH PT Yos Raya Timber Riau). Tesis. Institut Pertanian Bogor. Bogor. Tidak diterbitkan.

Wahyunto., S. Ritung., Suparto., dan H. Subagyo. 2005. Sebaran gambut dan kandungan karbon di Sumatera dan Kalimantan. Wetland International-Indonesia Programme. Bogor. 